\title{
A More Lovingly Made World
}

\author{
MCKENZIE WARK
}

THE NEW SCHOOL, NEW YORK CITY

Took my kids to Maker Faire, which describes itself as 'a two-day, family-friendly festival of invention, creativity and resourcefulness, and a celebration of the Maker movement.'1 It was basically in the parking lot of the Hall of Science, near where we live in Queens. We have a family membership so we got to skip the queue and go in through the members' line. 'Big crowd,' I said, to the ticket person. 'Oh, this is nothing,' she said. 'You should see us in Austin or California.' I guess New York City is not really a maker kind of place or, if it is, it's making something else.

My eight year old loved the knitting machines. We also soldered some circuits together, but he burned his finger. The best fun was a strange tricycle contraption you pedalled with your hands and steered with your butt. He loved that. My threeyear-old daughter loved the giant recreation of the Mousetrap game. ${ }^{2}$ And the Lego 'robots'. She has a thing about robots. I did not love that there was only one place selling coffee and the line was endless.

One of the good things about this version of maker culture is that it puts traditionally male and female kinds of amateur hobby stuff side by side. My son can 
try knitting; my daughter can play with Lego robots. There's a subtle reconfiguring of the hacker-hobby continuum going on. That's the good news.

On the other hand, it's not really about making things. It's like a homey version of what Nicholas Bourriaud called postproduction art. ${ }^{3}$ The stuff has already been made, you put it together. Like Ikea furniture, but, you know, fun. It probably isn't fun working in the factories that makes the circuit boards or the Lego bricks or the knitting machines.

So there's a short-circuit. It's about an amateur culture and a teaching culture that nibbles around the edges of a world that is made elsewhere. It's supposedly good training for labour in the creative and technical industries. You play with the end products to figure out how to make better 'user experiences' of products.

I'm in favour of knowing how things are made. But maker culture seems mostly about basic concepts, in electronics, for example, or knitting patterns. It is not about actual labour processes. The handicraft part depends on an industrial part that remains unseen. It's a kind of fetishism.

It was fun though, at least for the kids. We 'made' a bunch of stuff, bought more stuff to make, and went home. But it's hard to get into maker culture in New York City. We don't have dens or garages or spare rooms. This version of maker culture seems to assume a suburban everyday life, where there's space for some gratuitous making.

There is another version of maker culture in New York now, but it's different. Ironically, it's not about mechanical or electronic things, so much as about food and leather goods and furniture. The name for it is Brooklyn. ${ }^{4}$ Brooklyn is now home to all sorts of 'artisanal' industries, making everything from bacon to organic beard oil. It relies in part on proximity to under-utilised upstate farm land. There is also an urban farming movement, big enough to at least supply some quality restaurants. ${ }^{5}$

In a city so dominated by finance capital and its attendant services, this is both strange and quite inevitable. Brooklyn style-maker culture actually makes things, but it is things only rich people can really afford. It relies on a steady supply of rich people, all living one way or another off this being a money town.

Both of these maker cultures have their limitations, then. The Make Magazine or Maker Faire version really seems blind to the actual manufacturing of things, but it does at least open the door to a genuine popular culture about the material world. 
The Brooklyn maker culture really wants to get its hands dirty making things rather than just playing with things already made. But it doesn't scale. It makes a fetish of the artisanal quality of the labour as another way of avoiding the question of labour. Both kinds of making trip over certain conceptual problems.

What if we made 'making' - the process of labour on a resistant world-the central category of a certain kind of materialism? This would no longer be a contemplative materialism. While there's something to be said for the revival of realism in early twenty-first century thought, all the speculative realisms on offer are contemplative in nature. ${ }^{6}$ Marx's first thesis on Feuerbach still applies:

The chief defect of all hitherto existing materialism - that of Feuerbach included-is that the thing, reality, sensuousness, is conceived only in the form of the object of contemplation, but not as sensuous human activity, practice, not subjectively. Hence, in contradistinction to materialism, the active side was developed abstractly by idealism - which, of course, does not know real, sensuous activity as such. ${ }^{7}$

Marx's solution was to develop what Alexander Bogdanov (1873-1928) called the 'labour point of view.'8 This is an active materialism, the thought of the world as it is made by collective human labour. It does not claim to speak the eternal truths of the thing independent of our physical encounter with it. It is a historical materialism, but in the reverse of the usual sense. It does not proclaim universal laws of real historical development. Rather, materialist philosophy is itself always historical. It is limited by the form of the encounter with the material world itself by organised labour.

A corollary is that what can be said to be objectively true at any given moment is that which corresponds to the most general experience of collective labour. There may be progress or regress in such objectivity, but it is always limited by the way labour is organised at a given historical period. Thought is governed by what Bogdanov calls sociomorphism, meaning that the ways in which labour is organised at a given time come to be taken as the model of how the material world itself is organised.

For example, philosophies of causality as the command of one object by another are transpositions onto the material world of authoritarian organisational structures. Philosophies that split the spiritual realm from the temporal transpose 
the domination of a priestly class onto the realm of things themselves. As lord and priest command their estate and their flock so too God must command all things. Interestingly, those speculative realisms of today that hold that things withdraw not only from the subject but also from each other appear from this point of view as a kind of negative theology. They are a sociomorphism of the absence of power felt by scholastic discourse and of its indifference to the power of both labour and scientific-technical knowledge.

Bogdanov thought the highest stage in the labour point of view had to be that of the proletariat itself. He tried to affect a synthesis of the two components of such a materialism: those of manual and technical labour. He thought the age of the industrial machine was the last stage in the organisation of labour. As it turns out, this was not quite the case, and while there are intimations in Bogdanov, as early as 1908, of a cybernetic organisational point of view, he was not quite abreast of the full ramifications of how labour organisation would evolve and the expansions and limits to thought it might afford. ${ }^{9}$

All the same, there is much to be learned from Bogdanov's method, through which we might begin to tease out from experiences of forms of labour organisation in everyday life both the possibilities and limits to an objective world view of a given time. Particularly helpful here might be the work of one of Bogdanov's followers, Boris Arvatov (1896-1940). A contemporary of André Breton, Aratov's relation to the Marxist tradition could not be more different. Rather than extract from the everyday a marvellous poetics, Arvatov was more interested in how the things of the everyday are produced.10 Arvatov came of age with the October revolution, and thought seriously about the consequences of a mutation in the relations of production. While he does not use the term, design emerges as a central critical focus in his writing.

Arvatov on design points towards an approach to science and labour together as the collective processes of transforming the world of the unknowable object into a world of sensuous things, of objects rendered in human scale as everyday things. Design is the system of things that collective labour produces through the transformation of natural objects. For Arvatov, design is a total environment that is formed by and forms the human. 
Bourgeois culture sharply divides technical design from everyday design, or tools of production from commodities of consumption. In the wake of the 1917 revolution, Arvatov followed Bogdanov in thinking that a proletarian culture could overcome this distinction and create a new practice in which design no longer concerned itself just with the form of fetishised things made to float free on the market. Anything can be hacked, and by anyone-a universal maker culture. There would be no necessary distinction between the things of production and consumption. All things would at least potentially be common, rather than the property either of the owner of production or of the private individual who consumed it.11

The fetish of 'culture' as a separate domain is an effect of the divided form of the bourgeois thing. On the one hand, the machine as a productive thing is held to be outside culture; on the other hand, the 'finished' things of consumption, which make the material basis of culture, is seen as a separate realm.

Modernist design got as far as representing the machinery of production within the realm of consumption, but it did not break down the division. Arvatov: 'The alienation of consumption from production radically affects the Thing-relation in the sense that this relation becomes deeply subjective, ideological, and tastedetermined.' The things of culture are shaped by their design to appear as if they were outside a production process which nevertheless gives them their form.

Arvatov thought the rise of a technical intelligentsia created a new form for things even within capitalism. Like many Russian leftists of the 1920s, he loved the idea of New York City. ${ }^{12}$ The design of subway systems, office buildings, department stores and industrial laboratories created a material world that was at once technical and cultural. While these things were made within relations of private property, they were collective and cooperative in nature. The infrastructure of collective things was coming into being imperceptibly within capitalism. ${ }^{13}$

The technical intelligentsia that both formed and was formed by these new things could in turn create the basis of a new kind of culture, one no longer partitioned off within the sphere of consumption, where culture meant the contemplation of things separated from their means of production. The new culture would be one of both production and consumption, and resolutely social in character: A hacker world of processes rather than of objects and subjects, a real making-and-remaking culture. 
Design becomes less about perfecting the form of things and more about the shaping of the form of relations. It weaves its way between dynamic but supposedly soulless production and objectified but spiritual values in the cultural realm, replacing it with a 'monism of Things'. Arvatov: 'Not only did production methods begin to penetrate everyday life, but production itself was evolving ... infusing it with everyday life.' Arvatov looked forward to the abolition of the distinction between work and play, between technical object and cultural subject, professional and amateur. ${ }^{14}$

Even in this utopian vein, Arvatov saw the new world of massively socialised design as coming at a price: alienation from nature. The symptoms of this alienation could easily be read in early twentieth-century modern culture, both in its celebration of the artifice of the great city and its objects, as well as in the mythic longing for nature as an object of contemplation, outside collective labour and its transformative work upon it. Against this, Arvatov, like Bogdanov before him, writes 'the task of the proletariat is to create a systematically regulated dynamism of objects'.

It was not to be, in the Soviet Union or elsewhere. There was no class alliance of technicians and labour. Many things are systematically regulated, but the alienation of that dense net from nature has only increased. There was no collaborative design project in which the massively socialised forms of the modern city turned to the task of overcoming their alienation from the object-world that is their condition of existence. On the contrary, in both east and west reigned a division between the technicians and labour. Together they made a vastly expanded world of objects for private consumption. One class fashioned spectacular forms; the other shovelled in the content. ${ }^{15}$

Modernity is the transformation on an ever-expanding scale of intangible objects into tangible things. The fetish of subjectivity emerges out of the contemplation of such objects as things apart; things that are spiritualised precisely because they cannot be actualised in their material being as parts of a dynamism of objects that extends to the whole

In the overdeveloped world of the west, rather than an accumulation of the social powers of the city as the ultimate object of socialised design, suburbanisation extended the separate domain of private consumption from the bourgeoisie to the 
technical and labouring classes. Rather than confront the alienation from nature, suburbanisation took the image of nature as object of contemplation and carved it into a billion backyards. 16

From this point of view, both Maker Faire and Brooklyn maker culture appear as a sociomorphism of a particular kind: at worst, a compensatory reaction to the failure of precisely the sort of project Bogdanov and Arvatov outlined, but at best a modest series of tactics for keeping that project alive.

The utopian core of maker culture is a world in which all human activity is a collective practice of experimental labour on and with a resistant nature, with the aim of wresting freedom from necessity. Its critical dimension, however muted, points to the separation of the realms of producer things from consumer things. It wants the power to make all things available for remaking-what the Situationists called détournement. ${ }^{17}$

Naturally, this amateur labour falls short of any such goals. It becomes the paradoxical act of artisanal labour as consumption-Maker Faire. Or: acts of amateur artisanal production-Brooklyn culture-which aspire to professionalisation, and whose appeal is in the aura of craft but which is totally dependent on contemporary organisational logistics of the most impersonal kind.

The problem in Bogdanov and Arvatov's time appeared to be the integration of the point of view of technical organisational labour into that of manual labour. They understood how the labour process had changed since Marx's era. The problem today, at least in parts of the overdeveloped world like New York City, might be to integrate the point of view of manual labour back into a sociomorphism derived entirely from non-manual understandings of labour activity.

The only manual labour one usually comes into contact with in such a city is service industry labour designed to keep non-manual processes functioning, by cleaning our offices and making us coffee.18 The division of labour of which Arvatov spoke and its consequences for thought have become even more profound. Manual industrial labour has vastly expanded but is performed elsewhere.

Amateur labour processes-maker culture-at least provide some sort of pedagogic key within the spaces of everyday life in the overdeveloped world for at least asking questions about what labour is, and how the organisation of labour limits how the world can be thought objectively. Not least, it might provide a key to 
the critique of what became of critical theory within cultural studies broadly conceived.

While it is hard to live up to the strictures of Marx's eleventh thesis on Feuerbach, it seems that today even his first thesis-quoted above-is in the toohard basket. How can critical thought be both material and active? It seems as if it has split into two streams in which an active idealism and a contemplative materialism are even more irreconcilable. On the one hand, the various speculative realisms that reproduce the passive and purely abstract account of the real that Marx and Bogdanov critiqued.

On the other hand, active idealisms, repurposing Plato (Badiou) or Hegel (Zizek), in which only the Great Men are active in the world-including bizarre fanboy worshipping of Mao and of Bogdanov's nemesis within the Bolshevik party, Lenin. Amazingly, the most antique sociomorphism imaginable has also reappeared in the form of various hermeneutic fabulations upon Saint Paul (Badiou, Zizek, Agamben, Critchley). Excluded from both is the activity of labour, the labour point of view.

Given that the everyday was always the strong suit of cultural studies, perhaps the field can come into its own here, by developing a critique of how even critical thought is shaped by sociomorphism, by the limits of the organisation of social activity in everyday life. Perhaps more importantly, there are ways of restating the pedagogic dimension of cultural studies via an engagement with maker cultures.

It no longer seems so viable to make the practice-dimension of cultural studies a question of creating counter-hegemonic national-popular cultures of the Raymond Williams kind, let alone intervening in cultural policy. ${ }^{19}$ While there is something salutary in the focus on culture industries in that it attends to the vocational needs of students, it does not often rise to the level of a critique of the conjoining of those two concepts. But perhaps there is a practice-already existing-that could be further articulated in which the labour of the amateur can be critique rather than fetish within the given organisation of labour, an intimation within the everyday of a more lovingly made world. 
McKenzie Wark is professor of Media and Culture at The New School in New York City where he works in the areas of media theory, new media, critical theory, cinema, music and visual art. His most recent publications include A Hacker Manifesto (2004) and Dispositions (2002).

\footnotetext{
-NOTES

${ }^{1}$ See <http: / / makerfaire.com/newyork/2012/index.html>. Thanks to Garnet Hertz for the invitation to write about maker culture.

${ }^{2}$ See <http: / / lifesizemousetrap.wordpress.com/>.

${ }^{3}$ Nicholas Bourriaud, Postproduction, Lukas and Sternberg, New York, 2007.

${ }^{4}$ Benjamin Wallace, 'The Twee Party', New York, 15 April 2012,

<http: / / nymag.com/news / features / artisanal-brooklyn-2012-4/>.

${ }^{5}$ Lisa Foderaro, 'To Find Farms in New York City, Just Look Up', New York Times, 11 July 2012,

$<$ http: / / www.nytimes.com/ >.

${ }^{6}$ See Levi Bryant, Nick Srnicek and Graham Harman (eds), The Speculative Turn: Continental

Materialism and Realism, re:press, Melbourne, 2011.

${ }^{7}$ Karl Marx, 'Theses on Feuerbach',

<http://www.marxists.org/archive/marx/works/1845/theses/theses.htm>.

${ }^{8}$ See K.M. Jensen, Beyond Marx and Mach, Springer, Berlin, 1978.

${ }^{9}$ See Alexander Bogdanov, Red Star: The First Bolshevik Utopia, Indiana University Press, Bloomington IL, 1984.

${ }^{10}$ Boris Arvatov, 'Everyday Life and the Culture of the Thing', trans. Christina Kiaer, October, vol. 81, 1997, pp. 119-28. On constructivist design practice as one of the great historical avant gardes, see Christina Kiaer, Imagine No Possessions, MIT Press, Cambridge MA, 2008. Arvatov's theory of the split between the technical thing and the cultural thing anticipates Bruno Latour's concept of the two constitutions (science and politics), and provides a Marxist account of its genesis.

${ }^{11}$ I had not read Arvatov when I wrote $A$ Hacker Manifesto, Harvard University Press, Cambridge MA, 2004, but he clearly anticipates some of its themes.

12 See for instance Vladimir Mayakovsky, My Discovery of America, Hesperus, London, 2005.

${ }^{13}$ For examples of infrastructure studies see Lisa Parks, Cultures in Orbit: Satellites and the Televisual, Duke University Press, Durham NC, 2005 and Brian Larkin, Signal and Noise: Media, Infrastructure and Urban Culture in Nigeria, Duke University Press, Durham NC, 2008. While the work of Michael Hardt and Antonio Negri has much to recommend it, particularly compared to Leninite theologies, there's a certain privileging of living over dead labour that adheres to the concept of multitude that cuts it off from some of the questions I want to examine here.

${ }^{14}$ See Trebor Scholz (ed.), Digital Labor: The Internet as Playground and Factory, Routledge, 2012.

${ }^{15}$ See McKenzie Wark, The Beach Beneath the Street, Verso, London, 2011, p. 83ff. This separation of form and content was labelled 'tin can philosophy' by Asger Jorn. On the miserable failure of Soviet consumer goods industries, see Francis Spuford, Red Plenty, Greywolf, Minneapolis, 2012.

${ }^{16}$ See Jeanne Arnold, Anthony P. Graesch, Enzo Ragazzini and Elinor Ochs, Life At Home in the TwentyFirst Century: 32 Families Open Their Doors, Cotsen Institute of Archaeology, Los Angeles, 2012.

${ }^{17}$ Guy Debord and Gil Wolman, 'A User's Guide to Détournement',

$<$ http://www.bopsecrets.org/SI/detourn.htm>.

18 For a more nuanced view, see Joshua Freeman, Working Class New York: Life and Labor Since World

War II, New Press, New York, 2001.

${ }^{19}$ See Mark Gibson, Culture and Power: A History of Cultural Studies, Berg, London, 2007.
} 